\title{
Enhancing soil organic carbon, particulate organic carbon and microbial biomass in semi-arid rangeland using pasture enclosures
}

C. O. Oduor ${ }^{1 *}$, N. K. Karanja' ${ }^{1}$ R. N. Onwonga' ${ }^{1}$ S. M. Mureithi ${ }^{1}$, D. Pelster ${ }^{2,3}$ and G. Nyberg ${ }^{4}$

\begin{abstract}
Background: Rehabilitation of degraded rangelands through the establishment of enclosures (fencing grazing lands) is believed to improve soil quality and livelihoods, and enhance the sustainability of rangelands. Grazing dominated enclosure (GDE) and contractual grazing enclosure (CGE) are the common enclosure management systems in West Pokot County, Kenya. Under CGE, a farmer owning few animals leases the enclosure to households with relatively more livestock, while GDE is where the livestock utilizing the enclosure are purely owned by the farmer. Livestock management in both systems is via the free-range system. This study evaluated the effect of enclosure management on total soil organic carbon (SOC), particulate organic carbon (POC) and microbial biomass carbon (MBC) and nitrogen (MBN) as key indicators of soil degradation at 0-40 cm depth. The two enclosure systems were selected based on three age classes (3-10,11-20 and $>20$ years since establishment) $(n=3)$. The adjacent open grazing area $(\mathrm{OGR})$ was used as a reference $(n=9)$.

Results: Relative to OGR, the pasture enclosures significantly decreased soil bulk density and increased the concentrations of total organic C, POC, MBC and MBN compared to the degraded OGR $(P<0.001)$. Significantly higher concentrations of POC and MBC was recorded in GDE than CGE $(P=0.01)$. The POC accounted for $24.5-29.5 \%$ of the total SOC. MBC concentrations ranged from $32.05 \pm 7.25$ to $96.63 \pm 5.31 \mathrm{\mu g} \mathrm{C} \mathrm{g}^{-1}$ of soil in all grazing systems, and was positively correlated with total SOC and POC $(P<0.001)$. The proportional increase in $\mathrm{POC}$ and $\mathrm{MBC}$ was higher in GDE (56.6 and 30.5\% respectively) compared to CGE (39.2 and 13.9\% for POC and MBC respectively).

Conclusions: This study demonstrated that controlling livestock grazing through the establishment of pasture enclosures is the key strategy to enhance total SOC, POC, MBC, and MBN in degraded rangelands; a precondition for improving soil quality. Therefore, the establishment of enclosures is an effective restoration approach to restore degraded soils in semi-arid rangelands.
\end{abstract}

Keywords: Enclosure, Environmental microbiology, Land degradation, Microbial biomass, Organic carbon, Particulate carbon, Rehabilitation, Soil quality

\footnotetext{
${ }^{*}$ Correspondence: cllns.ouma07@gmail.com

${ }^{1}$ Department of Land Resource Management and Agricultural

Technology (LARMAT), University of Nairobi, P. O. Box 29053-00625,

Nairobi, Kenya

Full list of author information is available at the end of the article
}

C The Author(s) 2018. This article is distributed under the terms of the Creative Commons Attribution 4.0 International License (http://creativecommons.org/licenses/by/4.0/), which permits unrestricted use, distribution, and reproduction in any medium, provided you give appropriate credit to the original author(s) and the source, provide a link to the Creative Commons license, and indicate if changes were made. The Creative Commons Public Domain Dedication waiver (http://creativecommons.org/ publicdomain/zero/1.0/) applies to the data made available in this article, unless otherwise stated. 


\section{Background}

Human-induced soil degradation is a major concern globally [1,2], and has contributed to the decline in net primary productivity in arid and semi-arid lands [3]. Overgrazing in rangelands has altered the natural ecosystem, causing disturbances in biotic and abiotic components and livelihood of the community. Among the negative impacts of overgrazing is the loss of soil organic carbon (SOC), a scenario that occurs both in the temperate [4-6] and tropical rangelands [7, 8]. Soil organic carbon is the basis for soil fertility, the source of energy for soil microorganisms and regulates climate and biodiversity [9-12]. Restoration degraded rangelands have therefore attracted considerable attention in the recent past. The restoration of degraded grazing land may be important to improve the accumulation of SOC soil. The establishment of pasture enclosures by fencing degraded communal grazing areas has been reported to reduce the negative impacts of continuous grazing by preserving soil resources, leading to accumulation of SOC that was previously lost $[7,12,13]$. Understanding the dynamics and potential of soil to store organic carbon is not only essential for improving soil quality and enhancing the sustainability of rangelands in Sub-Saharan Africa, but also mitigate climate change by offsetting $\mathrm{CO}_{2}$ emissions $[4,14]$.

Soil organic carbon is regarded as an indicator of soil quality and by extension, the state of soil degradation as it determines soil structure, nutrient retention and supports biological diversity [15-17]. The reduction or loss of SOC could, therefore, lower soil fertility and consequently, lead to land degradation [18]. According to [13], the establishment of enclosure in a degraded rangeland resulted to a $34 \%$ increase in total SOC content in the upper $40 \mathrm{~cm}$ layer of soil. Besides, [19] recounted that degraded soils in semi-arid rangeland with low levels of organic carbon may be functionally improved by establishing pasture enclosures. However, [14] and [15] acknowledged that changes in total SOC require several years to detect. The labile fractions of total SOC include particulate organic carbon (POC) and microbial biomass carbon (MBC) [20]. These fractions may be more sensitive to land management than the total SOC. The POC acts as a substrate for soil microorganisms and influences soil nutrient cycles and biological properties of soil [21].

Livestock enclosures have gained cognizance as a successful tool for controlling heavy grazing and land degradation in Eastern Africa [19, 22-24]. In the arid and semi-arid rangelands of Western Kenya, efforts to restore degraded grazing lands through the establishment of pasture enclosures started in the mid-1980s [25]. As indicated by [26], grazing dominated enclosure (GDE) and contractual grazing enclosure (CGE) are the common types of enclosure management systems in West Pokot County, Kenya. The enclosures are privately owned and utilized, with an average size of 5 ha [26]. Contractual grazing represents a grazing arrangement where a farmer owning few animals leases the enclosure to households with relatively more livestock. On the other hand, GDE is where the livestock utilizing the enclosure is purely owned by the farmer. The stocking rate of the enclosures in the area ranges between 1 and 42 animals with a mean of 7 animals [26]. Livestock management in both CGE and GDE systems is via the free-range system. Previous studies in semi-arid rangelands show that POC and MBC concentrations increase after enclosing degraded grazing lands $[6,19,27]$, while others reported that grazing management has no significant impact on the dynamics of labile fractions of carbon $[28,29]$. These variations were attributed to differences in soils [30] and vegetation characteristics such as litter quantity and quality [31-33]. However, pasture management in the former studies was via cut-and-curry where livestock was not allowed to graze (excluded) in the enclosures.

Despite the fact that the practice of enclosures has existed in West Pokot County for over three decades, data on the effectiveness of these enclosures to restore degraded soils in terms of organic $\mathrm{C}$ in the area is lacking. Understanding the effect of enclosure management system and their age on SOC is crucial to offer the most effective carbon management options in rangelands. Based on the hypothesis that GDE enclosures are more effective to restore degraded soils than CGE enclosures by improving the content of soil organic carbon and microbial biomass, this study was carried out to determine the concentrations of total SOC, POC and MBC in CGE and GDE under three age-classes (3-10, 10-20, and $>20$ years since effective protection) with the similar quantifications in the adjacent open grazing areas as the baseline.

\section{Methods \\ Study site}

The study was conducted in Chepareria Ward $\left(01^{\circ} 18^{\prime} 17^{\prime \prime}-\right.$ $01^{\circ} 19^{\prime} 41^{\prime \prime} \mathrm{N}$ and $035^{\circ} 14^{\prime} 16^{\prime \prime}-035^{\circ} 15^{\prime} 49^{\prime \prime} \mathrm{E}, 1680 \mathrm{~m}$. a. s. l) in West Pokot County, Northwestern Kenya. The area is classified as semi-arid; receiving an average rainfall of $280 \mathrm{~mm}$ of rainfall for the short rains which occur between mid-October and January and $570 \mathrm{~mm}$ for the long rains which occur from mid-March to July [34]. The annual average daily air temperature ranges between 16 and $30{ }^{\circ} \mathrm{C}$ [34]. The soils are predominantly sandy clay to loamy sand and are classified as Haplic Lixisols [35]. Vegetation is predominantly grassland (Themeda triandra, Eragrostis superba, Cymbopogon validus, Cenchrus ciliaris and Cynodon dactylon) [36], with scattered native 
(Acacia spp., Balanites aegyptiaca, and Kigelia africana) and exotic (Grevillea robusta) tree species [22]. The average herbaceous vegetation cover range between $20.7 \%$ in open grazing rangeland and $40.2 \%$ in enclosure systems, with $72.0 \mathrm{~kg}$ dry matter (DM) $\mathrm{ha}^{-1}$ and $521.8 \mathrm{~kg} \mathrm{DM}$ $\mathrm{ha}^{-1}$ of herbaceous above-ground biomass in open grazing rangeland and enclosure respectively [36]. The traditional open grazing areas are characterized by free-range grazing of livestock with a stocking rate that exceeds the upper limit of the enclosure systems. The open grazing areas had a history of severe land degradation prior to the establishment of enclosures in mid-1980s by ViAgroforestry [25].

\section{Soil sampling}

Soil sampling was carried out during the short rain season, November 2016. In consultation with the local leaders and Vi-Agroforestry officials, the CGE and GDE enclosures were grouped into three age classes: $3-10$ years, $11-20$ years, and $>20$ years, and three enclosures were randomly selected from each enclosure type/ age class combination. A total of 18 enclosures were selected for sampling. Nine open grazing sites (OGR) were selected as controls $(n=9)$. This gave a total of 27 sampling sites. Within each enclosure/age class and in the adjacent open grazing areas, three 50-m transects were laid out in a Z-shaped orientation, at least $10 \mathrm{~m}$ from the edge to avoid edge effects. Along each transect, five sampling points were laid at $10 \mathrm{~m}$ apart and soil samples collected using a soil auger at $0-10,10-20$, and $20-40 \mathrm{~cm}$ depths. The five soil samples at each depth and within each transect were mixed to form a composite sample, producing three composite samples (one for each depth) for each transect and a total of nine composite samples (3 depths $\times 3$ transects) from each enclosure and open grazing site. A total of 243 soil samples were obtained (27 sampling sites $\times 9$ composite samples). About $0.5-\mathrm{kg}$ sub-sample was placed in air tight plastic bags for soil moisture determination, extraction of microbial biomass carbon $(\mathrm{MBC})$ and microbial biomass nitrogen (MBN). The remainder of the soil was air-dried, sieved through a 2-mm mesh and stored at $4{ }^{\circ} \mathrm{C}$ in a refrigerator for physical and chemical analyses. Steel cylinders of $98.2 \mathrm{~cm}^{-3}$ were used to obtain undisturbed soil samples for soil bulk density determinations, using the same sampling design. Within each transect, a $40 \mathrm{~cm}$ profile pit was dug in and one core sample taken in each depth, making a total of three core samples per transect.

\section{Soil analysis in the laboratory}

Soil water content was determined gravimetrically by oven-drying $100 \mathrm{~g}$ soil sub-sample at $105^{\circ} \mathrm{C}$ to constant weight for $48 \mathrm{~h}$ [37]. Soil $\mathrm{pH}$ and electrical conductivity
(EC) were determined in soil-water suspension in the ratio 1:2.5 (weight/volume). Soil $\mathrm{pH}$ was measured using a glass electrode $\mathrm{pH}$ meter (model: HI 2211, Hanna instruments), while EC was measured using a conductivity meter (model: HI 9812, Hanna Instruments). Soil bulk density (BD) was determined using core ring method by

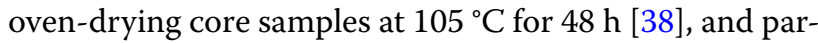
ticle size distribution using the hydrometer method [39]. Total soil organic carbon (SOC) was determined using the wet oxidation method [40], total nitrogen (TN) was determined using the Kjeldahl method [41] and cation exchange capacity (CEC) was determined by the ammonium acetate $\left(\mathrm{NH}_{4} \mathrm{OAc}\right)$ method as described by [42]

Physical fractionation was used to determine particulate organic carbon content, associated with the sand fraction $(2000-53 \mu \mathrm{m})$, following procedures by Cambardella and Elliott [43]. Approximately 20-g of sieved $(<2.0 \mathrm{~mm})$ air-dried soil sub-sample was dispersed with $70 \mathrm{ml}$ of 5 - $\mathrm{g} \mathrm{l}^{-1}$ sodium hexametaphosphate solution and the suspension was passed through a $53 \mu \mathrm{m}$ sieve using a jet distilled water. The material retained in the sieve was dried at $45^{\circ} \mathrm{C}$ for $48 \mathrm{~h}$ in a forced air oven. The ovendried material was ground and analyzed for organic carbon by the wet oxidation method [40] and TN using the Kjeldahl method [41].

Chloroform fumigation-extraction method was used to determine MBC and MBN contents in soil [44]. Ethanol-free chloroform was used to fumigate $10 \mathrm{~g}$ of fieldmoist soil samples for $24 \mathrm{~h}$ in a vacuum desiccator at room temperature. Another set of the same soil samples were not fumigated. The soluble $\mathrm{C}$ from the fumigated and non-fumigated samples was extracted with $50 \mathrm{ml}$ of $0.5-\mathrm{M} \mathrm{K}_{2} \mathrm{SO}_{4}$ solution. The extracted soil $\mathrm{MBC}$ was measured spectrophotometrically at $600 \mathrm{~nm}$. The difference between the extracted $\mathrm{C}$ in the fumigated and non-fumigated soils represented the microbial biomass $C$ [45]. MBN was determined by digesting $20 \mathrm{ml}$ of the soil extract using Kjeldahl digestion and the digest analyzed for total N. Correction factors (kc) of 0.45 and 0.54 were used for $\mathrm{MBC}$ and $\mathrm{MBN}$ respectively $[46,47]$.

\section{Statistical analysis}

Effects of grazing systems and soil depths, and enclosure type and age on total SOC, SOC fractions, microbial biomass, and the interactions were analyzed by two-way analysis of variance (ANOVA) using Genstat 15th edition [48]. Means were separated using Fischer's protected least significant difference (LSD) test at $P \leq 0.05$. Pearson correlation analyses were conducted to establish the relationship between soil organic carbon fractions and soil texture and microbial biomass carbon using SPSS 20th version [49]. 


\section{Results}

Soil physical and chemical characteristics

The sand, silt and clay contents were similar for all the grazing systems (Table 1). Soil bulk density in the $0-10 \mathrm{~cm}$ was lowered significantly from $1.49 \mathrm{~g} \mathrm{~cm}^{-3}$ in the OGR to 1.42 and $1.39 \mathrm{~g} \mathrm{~cm}^{-3}$ in CGE and GDE enclosures respectively $(P<0.001$, Table 1$)$. Soil moisture content was generally higher in the enclosures relative to the OGR and increased with depth. The enclosure system did not significantly alter soil $\mathrm{pH}$ and CEC (Table 1 ).

\section{Total soil organic carbon and nitrogen}

Grazing system and soil depth had significant $(P<0.001)$ effect on total SOC concentration. The proportion total SOC in the enclosures was $27.1 \%$ higher compared to OGR and the concentration decreased with depth (Table 2). However, the difference in SOC content between CGE and GDE was not significant. On the other hand, the values of total $\mathrm{N}$ content in CGE and GDE were similar but highly significant $(P<0.001)$ compared to total $\mathrm{N}$ content in OGR (Table 2). Within the enclosure systems, the age of enclosure had no effect on total SOC and TN concentrations $(P=0.52)$.

\section{Particulate organic carbon}

Grazing management significantly affected the concentration of POC (Table 3). The concentration of POC in the $0-10 \mathrm{~cm}$ increased significantly $(P<0.001)$ from $1.40 \pm 0.21$ in OGR to $2.01 \pm 0.26$ in CGE and $2.28 \pm 0.34 \mathrm{~g} \mathrm{~kg}^{-1}$ in GDE (Table 3). Unlike total SOC, the difference in POC content between CGE and GDE was significant $(P=0.01)$, but exhibited no significant variations among the age classes $(P=0.71)$. Relative to OGR, the proportion of POC in CGE and GDE was high by 38.8 and $55.2 \%$ respectively. In general, POC accounted for $24.5,27.1$ and $29.5 \%$ of the total SOC in OGR, CGE and GDE respectively.

Table 1 Soil physical and chemical properties under different grazing management systems in Chepareria, Kenya

\begin{tabular}{|c|c|c|c|c|c|c|c|c|}
\hline Grazing system & Soil depth (cm) & $\mathrm{pH}$ & $\begin{array}{l}\text { CEC } \\
\mathrm{Cmol} \mathrm{kg}^{-1}\end{array}$ & $\begin{array}{l}\text { Sand } \\
\%\end{array}$ & Silt & Clay & Moisture content & $\begin{array}{l}\mathrm{BD} \\
\mathrm{g} \mathrm{cm}^{-3}\end{array}$ \\
\hline \multirow[t]{3}{*}{ GDE } & $0-10$ & $6.1 \pm 0.55$ & $8.0 \pm 1.03$ & $78.7 \pm 2.61$ & $5.4 \pm 1.62$ & $13.6 \pm 1.17$ & $6.79 \pm 2.27 \mathrm{bc}$ & $1.39 \pm 0.10 b c$ \\
\hline & $10-20$ & $6.1 \pm 0.30$ & $8.3 \pm 0.93$ & $77.8 \pm 2.52$ & $5.7 \pm 2.37$ & $14.2 \pm 1.09$ & $7.28 \pm 2.29 a b c$ & $1.37 \pm 0.05 c$ \\
\hline & $20-40$ & $6.0 \pm 0.34$ & $9.1 \pm 0.78$ & $78.2 \pm 2.52$ & $6.0 \pm 2.00$ & $14.0 \pm 1.15$ & $8.16 \pm 2.23 a b$ & $1.36 \pm 0.06 c$ \\
\hline \multirow[t]{3}{*}{ CGE } & $0-10$ & $6.2 \pm 0.22$ & $8.2 \pm 0.75$ & $81.3 \pm 1.29$ & $7.8 \pm 1.60$ & $13.4 \pm 1.21$ & $6.32 \pm 2.76 c$ & $1.42 \pm 0.10 \mathrm{abc}$ \\
\hline & $10-20$ & $6.0 \pm 0.61$ & $8.7 \pm 0.95$ & $80.6 \pm 1.57$ & $8.0 \pm 2.23$ & $13.7 \pm 1.16$ & $6.83 \pm 2.68 \mathrm{bc}$ & $1.46 \pm 0.10 \mathrm{ab}$ \\
\hline & $20-40$ & $6.2 \pm 0.24$ & $8.6 \pm 1.16$ & $80.6 \pm 1.60$ & $7.7 \pm 2.88$ & $13.4 \pm 1.18$ & $8.51 \pm 2.44 a$ & $1.45 \pm 0.05 \mathrm{ab}$ \\
\hline \multirow[t]{3}{*}{ OGR } & $0-10$ & $6.3 \pm 0.27$ & $9.0 \pm 0.92$ & $79.5 \pm 1.61$ & $6.8 \pm 1.88$ & $13.8 \pm 1.29$ & $5.85 \pm 2.51 c$ & $1.49 \pm 0.05 a$ \\
\hline & $10-20$ & $5.2 \pm 0.56$ & $8.6 \pm 0.95$ & $78.9 \pm 1.57$ & $7.3 \pm 2.09$ & $13.7 \pm 1.30$ & $6.38 \pm 2.55 c$ & $1.47 \pm 0.06 a$ \\
\hline & $20-40$ & $5.0 \pm 0.24$ & $8.7 \pm 0.90$ & $78.7 \pm 1.48$ & $7.2 \pm 1.75$ & $13.9 \pm 1.17$ & $6.78 \pm 2.22 \mathrm{bc}$ & $1.47 \pm 0.06 a$ \\
\hline $\mathrm{LSD}_{0.05}$ & & NS & NS & NS & NS & NS & 1.13 & 0.07 \\
\hline $\mathrm{CV} \%$ & & 6.6 & 10.7 & 2.4 & 31.8 & 8.7 & 15 & 5.2 \\
\hline P-value & & 0.13 & 0.56 & 0.16 & 0.08 & 0.168 & 0.01 & $<0.001$ \\
\hline
\end{tabular}

Values are mean $\pm S D(n=9)$. Different lowercase letters within the same column indicate significant differences between means at $P \leq 0.05$

NS not significant, GDE grazing dominated enclosure, CGE contractual grazing enclosure, OGR open grazing rangeland, CV\% coefficient of variation

Table 2 Soil organic carbon and total nitrogen concentrations at three depths under different grazing management systems

\begin{tabular}{|c|c|c|c|c|c|c|}
\hline \multirow[t]{2}{*}{ Depth (cm) } & \multicolumn{3}{|c|}{ Total soil organic carbon $\left(\mathrm{g} \mathrm{kg}^{-1}\right)$} & \multicolumn{3}{|c|}{ Total nitrogen $\left(\mathrm{g} \mathrm{kg}^{-1}\right)$} \\
\hline & OGR & CGE & GDE & OGR & CGE & GDE \\
\hline $0-10$ & $4.93 \pm 0.69 \mathrm{Ba}$ & $6.22 \pm 0.78 \mathrm{Aa}$ & $6.61 \pm 0.89 \mathrm{Aa}$ & $0.53 \pm 0.07 \mathrm{Ba}$ & $0.63 \pm 0.08 \mathrm{Aa}$ & $0.65 \pm 0.08 \mathrm{Aa}$ \\
\hline $10-20$ & $4.88 \pm 0.65 \mathrm{Ba}$ & $5.86 \pm 0.67 \mathrm{Aa}$ & $6.28 \pm 0.99 \mathrm{Aa}$ & $0.58 \pm 0.11 \mathrm{Ba}$ & $0.63 \pm 0.08 \mathrm{Aa}$ & $0.61 \pm 0.07 \mathrm{ABa}$ \\
\hline $20-40$ & $4.36 \pm 0.74 \mathrm{Bb}$ & $5.57 \pm 0.57 \mathrm{Ab}$ & $5.47 \pm 0.77 \mathrm{Ab}$ & $0.52 \pm 0.10 \mathrm{Bb}$ & $0.61 \pm 0.08 \mathrm{Aa}$ & $0.59 \pm 0.07 \mathrm{Ab}$ \\
\hline Pooled mean & $4.72 \pm 0.73 B$ & $5.88 \pm 0.72 \mathrm{~A}$ & $6.12 \pm 1.00 \mathrm{~A}$ & $0.54 \pm 0.09 B$ & $0.62 \pm 0.08 \mathrm{~A}$ & $0.62 \pm 0.08 \mathrm{~A}$ \\
\hline
\end{tabular}

Values are mean $\pm S D(n=9)$. Values with different uppercase letters across the rows (grazing systems) and the lowercase letters within columns (soil depths) are significantly different at $P<0.05$

OGR Open grazing rangeland, CGE contractual grazing enclosure, GDE grazing dominated enclosure 
Table 3 Distribution of particulate organic carbon with depth in three grazing systems in Chepareria, Kenya

\begin{tabular}{|c|c|c|c|c|c|c|}
\hline \multirow[t]{2}{*}{ Depth (cm) } & \multicolumn{3}{|c|}{ Particulate organic carbon $\left(\mathrm{g} \mathrm{kg}^{-1}\right)$} & \multicolumn{3}{|c|}{ Particulate organic nitrogen $\left(\mathrm{g} \mathrm{kg}^{-1}\right)$} \\
\hline & OGR & CGE & GDE & OGR & CGE & GDE \\
\hline $0-10$ & $1.40 \pm 0.21 \mathrm{Ca}$ & $2.01 \pm 0.26 \mathrm{Ba}$ & $2.28 \pm 0.34 \mathrm{Aa}$ & $0.19 \pm 0.12 \mathrm{Aa}$ & $0.16 \pm 0.04 \mathrm{Aa}$ & $0.16 \pm 0.03 \mathrm{Ab}$ \\
\hline $10-20$ & $1.20 \pm 0.24 \mathrm{Cb}$ & $1.52 \pm 0.26 \mathrm{Bb}$ & $1.80 \pm 0.25 \mathrm{Ab}$ & $0.17 \pm 0.07 \mathrm{Aa}$ & $0.18 \pm 0.02 \mathrm{Aa}$ & $0.18 \pm 0.04 \mathrm{Aab}$ \\
\hline $20-40$ & $0.88 \pm 0.15 \mathrm{BC}$ & $1.31 \pm 0.16 \mathrm{AC}$ & $1.32 \pm 0.19 A C$ & $0.18 \pm 0.04 \mathrm{Aa}$ & $0.18 \pm 0.05 \mathrm{Aa}$ & $0.20 \pm 0.03 \mathrm{Aa}$ \\
\hline Pooled mean & $1.16 \pm 0.30 \mathrm{C}$ & $1.61 \pm 0.37 \mathrm{~B}$ & $1.80 \pm 0.50 \mathrm{~A}$ & $0.18 \pm 0.07 \mathrm{~A}$ & $0.17 \pm 0.05 \mathrm{~A}$ & $0.18 \pm 0.04 \mathrm{~A}$ \\
\hline
\end{tabular}

Values represent mean $\pm S D(n=9)$. Values with different uppercase letters across the rows (grazing systems) and the lowercase letters within columns (soil depths) are significantly different at $P<0.05$

GDE grazing dominated enclosure, CGE contractual grazing enclosure, OGR open grazing range

\section{Microbial biomass carbon and nitrogen}

Enclosures significantly increased $\mathrm{MBC}$ and $\mathrm{MBN}$, with higher concentrations observed in the $0-10 \mathrm{~cm}$ depth in all the grazing systems $(P<0.001$, Table 4$)$. Compared to the mean $\mathrm{MBC}$ recorded in OGR, the MBC contents in CGE and GDE significantly increased by $13.9 \%$ and $30.5 \%$ $(P<0.001)$. Within the enclosures, significantly higher concentration of $\mathrm{MBC}$ was observed in GDE relative to CGE $(P=0.01)$. However, $\mathrm{MBC}$ and $\mathrm{MBN}$ concentrations were similar across the enclosure age classes $(P=0.63$ and 0.97 for $\mathrm{MBC}$ and $\mathrm{MBN}$ respectively).

Relationship between SOC, TN, POC and Microbial biomass Total SOC exhibited significant $(P<0.001)$ positive correlation with TN, POC and MBC at all soil depths, but was only significant with PN at 10-20 cm depth (Table 5). Total nitrogen showed significant relationship with POC at all soil depths and with $\mathrm{MBC}$ at the surface $0-10 \mathrm{~cm}$ only. The POC positively associated with $\mathrm{MBC}$ at all soil depths with the relationship being stronger at the surface $0-10 \mathrm{~cm}(r=0.63)$ compared to $10-20$ and $20-40 \mathrm{~cm}$ depths ( $r=0.57$ and 0.41 respectively) (Table 5).

\section{Discussion}

Similarities in soil $\mathrm{pH}$, texture and CEC indicated that areas inside enclosures were comparable to the communal grazing lands prior to the establishment of enclosures and that differences in the measured variables among the studied sites were caused by land use change and not by inherent site variability. Low CEC indicated the deficiency of significant amounts of exchangeable cations such as $\mathrm{Ca}^{2+}, \mathrm{Mg}^{2+}$, and $\mathrm{K}^{+}$[50]. Despite the fact that the top-soil bulk density in all the grazing systems were generally below the root-restricting value of $1.80 \mathrm{~g} \mathrm{~cm}^{-3}$ for loamy sand soils [51], the lower bulk density under GDE and CGE indicated the potential of enclosures to improve soil physical properties such as compaction that hamper critical soil functions, like the capture, storage and supply of water for plants [52]. This result agreed with [53] who showed that grazing exclusion sites reduced soil bulk density compared to the adjacent continuous grazing sites in the sandy grassland of Inner Mongolia, China. Higher soil moisture content in CGE and GDE could perhaps be as a result of the improved soil physicochemical properties. The reduced soil bulk density in the enclosed systems may have increased the rate of water infiltration in the soil due to high pore space. As indicated by [54], low water infiltration rates in degraded grasslands relative to enclosed sites were due to the high soil compaction induced by the grazing livestock. On the other hand, higher SOC in the enclosures increased the capacity of the soil to retain moisture [55]. Increase in moisture with depth may be due to high evaporative loss at the soil surface than in the deep soil horizons.

Table 4 Distribution of microbial biomass carbon and nitrogen with depth in three grazing systems in Chepareria, Kenya

\begin{tabular}{|c|c|c|c|c|c|c|}
\hline \multirow[t]{2}{*}{ Depth (cm) } & \multicolumn{3}{|c|}{ Microbial biomass carbon $\left(\mu \mathrm{g} \mathrm{g}^{-1}\right)$} & \multicolumn{3}{|c|}{ Microbial biomass nitrogen $\left(\mu \mathrm{g} \mathrm{g}^{-1}\right)$} \\
\hline & OGR & CGE & GDE & OGR & CGE & GDE \\
\hline $0-10$ & $77.08 \pm 5.25 \mathrm{Ca}$ & $88.22 \pm 6.16 \mathrm{Ba}$ & $96.63 \pm 5.31 \mathrm{Aa}$ & $37.57 \pm 2.01 \mathrm{Ba}$ & $38.44 \pm 2.26 \mathrm{Ba}$ & $40.9 \pm 5.68 \mathrm{Aa}$ \\
\hline $10-20$ & $73.67 \pm 4.27 \mathrm{Cb}$ & $81.05 \pm 3.74 \mathrm{Bb}$ & $94.10 \pm 5.55 \mathrm{Aa}$ & $36.24 \pm 2.50 \mathrm{Aa}$ & $37.57 \pm 3.45 \mathrm{Ab}$ & $37.89 \pm 3.30 \mathrm{Ab}$ \\
\hline $20-40$ & $32.05 \pm 7.25 \mathrm{Cc}$ & $38.94 \pm 10.42 B C$ & $47.77 \pm 6.04 \mathrm{Ab}$ & $18.01 \pm 3.71 \mathrm{Cb}$ & $22.09 \pm 3.04 \mathrm{Ac}$ & $21.64 \pm 3.34 \mathrm{AC}$ \\
\hline Pooled mean & $60.93 \pm 21.36 C$ & $69.40 \pm 23.04 B$ & $79.50 \pm 23.28 \mathrm{~A}$ & $31.97 \pm 7.49 B$ & $31.34 \pm 10.00 B$ & $33.48 \pm 9.49 A$ \\
\hline
\end{tabular}

Values represent mean $\pm S D(n=9)$. Values with different uppercase letters across the rows (grazing systems) and the lowercase letters within columns (soil depths) are significantly different at $P<0.05$

GDE grazing dominated enclosure, CGE contractual grazing enclosure, OGR open grazing rangeland 
Table 5 Linear correlation analysis of SOC, TN, POC, PON, MBC and MBN in the three soil depths $(n=81)$

\begin{tabular}{|c|c|c|c|c|c|c|}
\hline Depth (cm) & SOC & TN & POC & PN & MBC & MBN \\
\hline \multicolumn{7}{|l|}{$0-10$} \\
\hline SOC & - & & & & & \\
\hline $\mathrm{TN}$ & $0.71^{* *}$ & - & & & & \\
\hline POC & $0.86^{* *}$ & $0.70^{* *}$ & - & & & \\
\hline PN & 0.06 & 0.10 & 0.04 & - & & \\
\hline$M B C$ & $0.57^{* *}$ & $0.46^{* *}$ & $0.63^{* *}$ & 0.18 & - & \\
\hline MBN & $0.32^{* *}$ & 0.10 & $0.38^{* *}$ & 0.01 & $0.21^{*}$ & - \\
\hline \multicolumn{7}{|l|}{$10-20$} \\
\hline SOC & - & & & & & \\
\hline TN & $0.54^{* *}$ & - & & & & \\
\hline POC & $0.81^{* *}$ & $0.42^{* *}$ & - & & & \\
\hline PN & $0.29 * *$ & 0.14 & $0.25^{*}$ & - & & \\
\hline$M B C$ & $0.40^{* *}$ & 0.06 & $0.57^{* *}$ & 0.15 & - & \\
\hline MBN & 0.04 & 0.10 & 0.03 & 0.16 & 0.18 & - \\
\hline \multicolumn{7}{|l|}{$20-40$} \\
\hline SOC & - & & & & & \\
\hline $\mathrm{TN}$ & $0.66^{* *}$ & - & & & & \\
\hline POC & $0.91^{* *}$ & $0.65^{* *}$ & - & & & \\
\hline PN & 0.16 & 0.19 & 0.14 & - & & \\
\hline$M B C$ & $0.30^{* *}$ & 0.09 & $0.41^{* *}$ & 0.10 & - & \\
\hline MBN & 0.17 & 0.14 & 0.17 & 0.00 & 0.05 & - \\
\hline
\end{tabular}

Values are correlation coefficient, $r$

$S O C$ total soil organic carbon, $T N$ total nitrogen, $P O C$ particulate organic carbon, $P O N$ particulate organic nitrogen, $M B C$ microbial biomass carbon, $M B N$ microbial biomass nitrogen

* Denotes significant correlation at the 0.05 level

** Denotes significant correlation at the 0.01 level: others are not significant

Irrespective of land use, the amounts of SOC and TN in soil are determined by the balance between organic matter inputs and losses [56]. The significantly higher level of SOC and TN in the enclosures compared to the open grazing land was probably because of the reduced soil disturbance by grazing animals. This prompted the production of aboveground biomass [36], thereby facilitating the accumulation and storage of $\mathrm{C}$ into the soil and its mineralization releasing nitrogen. According to [36, 53, 57], high removal of forage by the grazing animals in open grazing lands reduces herbaceous vegetation cover and accumulation of aboveground biomass. Consequently, this reduced the amount of $\mathrm{C}$ incorporated into the soil in open grazing lands. In addition, the high bulk density in the surface $0-10 \mathrm{~cm}$ and low soil moisture content in OGR could have reduced the input of soil organic matter by hampering storage and supply of water for plant growth [52, 54]. The reduction in SOC with increasing soil depth in all grazing systems suggests that organic matter accumulation in the surface $0-10 \mathrm{~cm}$ was higher than in the $10-20 \mathrm{~cm}$ and $20-40 \mathrm{~cm}$ depths. Higher SOC in the $10-20 \mathrm{~cm}$ and $20-40 \mathrm{~cm}$ in CGE and GDE relative to OGR could be as a result of the reduced grazing activities, which promoted root growth and accumulation of root biomass [33]. This facilitated the incorporation organic $\mathrm{C}$ in the subsoil. The reduction in SOC content with increasing soil depth is consistent with previous research in semi-arid rangelands in Tigray, Ethiopia and Inner Mongolia in China $[7,58]$. These results corroborate with studies conducted in semiarid grasslands in Northern and Eastern Ethiopia and in Northwestern Kenya where higher soil organic $C$ in enclosures was attributed to increased biomass production and reduced trampling by the grazing livestock $[7,8,19]$. Age of enclosure did not influence SOC levels because enclosures are continuously used for periodic grazing. This agrees with other studies in the area $[59,60]$. Furthermore, the $\sim 30$ years of existence of enclosures in the area could be a short time to detect the changes in total organic carbon [61].

The higher concentration of POC in the enclosures suggested that the accumulation of organic matter was higher in the fenced areas than in the open grazing areas. Compared to total SOC, the considerably higher POC content in GDE than in CGE implied that POC is more sensitive to changes in grazing management. 
The results were consistent with $[62,63]$ who reported that particulate organic carbon responds to changes in grazing management compared to total SOC. Higher concentration of POC in GDE relative to CGE and OGR may be due to the lower grazing pressure which reduced soil disturbance. The reduced soil disturbance permitted the protection of soil organic matter from decomposition. According to $[64,65]$, trampling by livestock disintegrates soil macro-aggregates thus exposing soil organic matter to decomposition. The incorporation and stabilization of particulate organic matter into soil aggregates is a dominant factor for protecting organic carbon in grazing lands [66-68]. In addition, the higher herbaceous vegetation cover observed in CGE and GDE compared to OGR [36], greatly contributed to the conservation of $\mathrm{POC}$ in the enclosures by reducing erosion. Higher levels of POC in the surface $0-10 \mathrm{~cm}$ soil compared to $10-20$ and 20-40 depths suggest that plant roots supplied more organic matter in the surface soil compared to the subsoil. The sandy nature of soils in this study (Table 1) implies that the POC have low colloidal protection, and consists mainly of partially humified plant residues. The proportion of POC of the total SOC in this study (24.5-29.5\%) was within the reported ranges of between 2 and $>50 \%$ in semiarid grasslands [69-71].

Similar to the trends observed with POC, the significantly higher contents of $\mathrm{MBC}$ and $\mathrm{MBN}$ in the GDE and CGE compared to OGR was attributed to the increased concentration of POC in the enclosures which acted as a source of energy for soil microbiota. This was supported by the significant positive correlation exhibited between $\mathrm{MBC}$ and $\mathrm{POC}$ in all soil depths. Moreover, the significant decrease in $\mathrm{MBC}$ and MBN content with depth in all the grazing systems indicated a higher potential for organic matter inputs from root exudates and plant litter in the surface soil relative to the deeper soils [72]. These results were consistent with studies by Wu $[6,19]$ in a semi-arid rangeland in North-Western Kenya and Hulunbuir grassland of Inner Mongolia where higher microbial biomass $\mathrm{C}$ and $\mathrm{N}$ contents were recorded in enclosed areas than in the open grazing lands. The range of microbial biomasses $C$ recorded in this study (32.1$96.6 \mu \mathrm{g} \mathrm{g}^{-1}$ soil) was relatively low compared to those recorded in Baringo County in Kenya (73-156 $\mu \mathrm{g} \mathrm{g}^{-1}$ soil) [19]. This could be attributed to the differences in soil type and management strategies in the two areas. However, it has been recognized that microbial biomass recovers slowly in sandy soils in semiarid climates $[64,73]$. Nonsignificant variations in POC and microbial biomass levels among the enclosure age classes could be the short residence time soluble fractions of organic C $[74,75]$.

\section{Conclusions}

This study showed that the soils in the semi-arid rangelands of West Pokot County are very fragile. Relative to the enclosure systems, continuous grazing in the open grazing land caused a considerable increase soil bulk density and additional loss of total SOC, total N, POC, and microbial biomass contents. The observed variations in all these parameters indicated that the communal grazing lands were in a degraded state. This may portray serious consequence for soil quality, plant growth and loss of livelihood in tropical rangelands where grazing is the major land-use. Restoration of the degraded grazing land via the establishment of pasture enclosures increased the contents total SOC and total $\mathrm{N}$ and reduced soil bulk density. The concentrations of POC, MBC and MBN were considerably higher in GDE than in CGE. The results supported the hypothesis that GDE enclosures are more effective to restore degraded soils than CGE enclosures. This indicates that the degraded soils in the open grazing land can indeed recover following the establishment of enclosure. The POC and $\mathrm{MBC}$ were more sensitive to grazing management than total SOC and can be used as indicators of the soil $\mathrm{C}$ dynamics in semi-arid rangelands. Therefore, this study demonstrated that controlling livestock grazing through the establishment of enclosures is integral to increase SOC stocks or reduce its losses; a precondition for improving soil quality and climate change mitigation. Future research should focus on enclosures carrying capacity and seasonal ecosystem dynamics of carbon and nitrogen to better understand the ecology of this fragile ecosystem.

\section{Abbreviations \\ ANOVA: analysis of variance; BD: bulk density; CEC: cation exchange capacity; CGE: contractual grazing enclosure; DM: dry matter; EC: electrical conductivity; GDE: grazing dominated enclosure; LSD: least significance difference; MBC: microbial biomass carbon; MBN: microbial biomass nitrogen; OGR: open graz- ing rangeland; POC: particulate organic carbon; SOC: soil organic carbon; TN: total nitrogen.}

\section{Authors' contributions}

All authors contributed to the development of the concept and implementation of the study. $\mathrm{COO}$ carried out field data collection, data analysis and drafted the manuscript. NKK, RNO, SMM, DP and GN made comments on the manuscript. All authors read and approved the final manuscript.

\section{Author details}

${ }^{1}$ Department of Land Resource Management and Agricultural Technology (LARMAT), University of Nairobi, P. O. Box 29053-00625, Nairobi, Kenya. ${ }^{2}$ Mazingira Centre, International Livestock Research Institute, P. O. Box 30709-00100, Nairobi, Kenya. ${ }^{3}$ Agriculture and Agri-Food Canada, Science and Technology Branch, Quebec City, Canada. ${ }^{4}$ Department of Forest Ecology and Management, Swedish University of Agricultural Sciences (SLU), 90183 Umeå, Sweden. 


\section{Acknowledgements}

The authors are grateful to SLEEK'System for Land-based Emission Estimation in Kenya'"http://www.sleek.environment.go.ke/" and Triple L research initiative "http://www.triplel.se" for the financial support. Sincere thanks goes to Mr. Bernard Lokorwa of Vi-Agroforestry for facilitating the field work. Authors also appreciate Dr. Alexandre Strapasson of Harvard University and Imperial College London for his mentorship via the International Support Network for African Development (ISNAD).

\section{Competing interests}

The authors declare that they have no competing interests.

\section{Availability of data and materials}

We are not able to the share research data publicly but can be made available upon request.

\section{Consent for publication}

Not applicable.

\section{Ethics approval and consent to participate}

Not applicable.

\section{Funding}

This study was funded by the SLEEK'System for Land-based Emission Estimation in Kenya' project, http://www.sleek.environment.go.ke/ in collaboration with Triple L research initiative, http://www.triplel.se.

\section{Publisher's Note}

Springer Nature remains neutral with regard to jurisdictional claims in published maps and institutional affiliations.

Received: 26 February 2018 Accepted: 27 October 2018

Published online: 06 November 2018

\section{References}

1. Oldeman LR. Global extent of soil degradation. In: Bi-Annual Report 1991-1992/ISRIC; 1992. p. 16-36.

2. Oldeman LR, Hakkeling RTA, Sombroek WG, World map of the status of human-induced soil degradation: an explanatory note; 2017. http:// wedocs.unep.org/bitstream/handle/20.500.11822/19660/ExplanNote _1.pdf? sequence=1. Accessed 20 Oct 2018.

3. Zika M, Erb KH. The global loss of net primary production resulting from human-induced soil degradation in drylands. Ecol Econ. 2009:69(2):310-8.

4. Hafner $\mathrm{S}$, et al. Effect of grazing on carbon stocks and assimilate partitioning in a Tibetan montane pasture revealed by $13 \mathrm{CO} 2$ pulse labeling. Glob Change Biol. 2012;18(2):528-38

5. Holt J. Grazing pressure and soil carbon, microbial biomass and enzyme activities in semi-arid northeastern Australia. Appl Soil Ecol. 1997;5(2):143-9.

6. Wu X, et al. Restoration of ecosystem carbon and nitrogen storage and microbial biomass after grazing exclusion in semi-arid grasslands of Inner Mongolia. Ecol Eng. 2014;73:395-403.

7. Mussa M, Ebro A, Nigatu L. Soil organic carbon and total nitrogen stock response to traditional enclosure management in eastern Ethiopia. J Soil Sci Environ Manag. 2017:8(2):37-43.

8. Mekuria W, et al. Restoration of ecosystem carbon stocks following exclosure establishment in communal grazing lands in Tigray, Ethiopia. Soil Sci Soc Am J. 2011:75:246-56.

9. Lal R. Carbon sequestration in dryland ecosystems. Environ Manage. 2004;33:528-44.

10. Dou $X$, et al. Soil organic carbon dynamics under long-term fertilization in a black soil of China: evidence from stable C isotopes. Sci Rep. 2016;6:21488

11. Lal R. Societal value of soil carbon. J Soil Water Conserv. 2014;69:188a-92a.

12. Li XL, et al. Rangeland degradation and the Qinghai-Tibet plateau: implications for rehabilitation. Land Degrad Dev. 2013;24:72-80.
13. Wang S, et al. Management and land use change effects on soil carbon in northern China's grasslands: a synthesis. Agr Ecosyst Environ. 2011:142(3):329-40.

14. Savadogo P, Sawadogo L, Tiveau D. Effects of grazing intensity and prescribed fire on soil physical and hydrological properties and pasture yield in the savanna woodlands of Burkina Faso. Agr Ecosyst Environ. 2007:118:80-92.

15. Chazdon RL. Beyond deforestation: restoring forests and ecosystem services on degraded lands. Science. 2008:320(5882):1458-60.

16. Gil-Sotres F, et al. Different approaches to evaluating soil quality using biochemical properties. Soil Biol Biochem. 2005;37:877-87.

17. Giller KE, et al. Agricultural intensification, soil biodiversity and agroecosystem function. Appl Soil Ecol. 1997;6(1):3-16.

18. Rounsevell M, Evans S, Bullock P. Climate change and agricultural soils: impacts and adaptation. Clim Change. 1999;43(4):683-709.

19. Mureithi SM, et al. Impact of enclosure management on soil properties and microbial biomass in a restored semi-arid rangeland, Kenya. J Arid Land. 2014:6(5):561-70.

20. Weil RR, et al. Estimating active carbon for soil quality assessment: a simplified method for laboratory and field use. Am J Altern Agric. 2003;18:3-17

21. Weil RR, Magdoff F. Significance of soil organic matter to soil quality and health. In: Magdoff F, Weil RR, editors. Soil organic matter in sustainable agriculture. Boca Raton: CRC Press; 2004.

22. Makokha W, et al. We work together: land rehabilitation and household dynamics in Chepareria Division, west Pokot District, Kenya. RELMA Technical Report No. 22. Nairobi Kenya: RELMA/SIDA. ISBN 9966-896-42-2. p. 1999(81)

23. Mekuria W, et al. Effectiveness of exclosures to restore degraded soils as a result of overgrazing in Tigray, Ethiopia. J Arid Environ. 2007;69(2):270-84.

24. Mwilawa A, Komwihangilo D, Kusekwa M. Conservation of forage resources for increasing livestock production in traditional forage reserves in Tanzania. Afr J Ecol. 2008;46(s1):85-9.

25. Vi-Agroforestry, West Pokot Progressive Survey Report 2007. In: O. K. O. Compiled by M\&E Team: Lonah Mukoya, Joseph Mwaniki, Wairimu Njuguna, Editors. Vi-Agroforestry Project, Kitale; 2007.

26. Wairore JN, et al. Characterization of enclosure management regimes and factors influencing their choice among agropastoralists in North-Western Kenya Pastoralism: research. Policy Pract. 2015;5(1):14.

27. Silveira $M L$, et al. Short-term effects of grazing intensity and nitrogen fertilization on soil organic carbon pools under perennial grass pastures in the southeastern USA. Soil Biol Biochem. 2013:58:42-9.

28. Pringle $M$, et al. The effect of pasture utilization rate on stocks of soil organic carbon and total nitrogen in a semi-arid tropical grassland. Agr Ecosyst Environ. 2014;195:83-90.

29. Stavi I, et al. No adverse effect of moderate stubble grazing on soil quality and organic carbon pool in dryland wheat agro-ecosystems. Agron Sustain Dev. 2015;35(3):1117-25.

30. Bruun TB, et al. Organic carbon dynamics in different soil types after conversion of forest to agriculture. Land Degrad Dev. 2015;26(3):272-83.

31. Castellano MJ, et al. Integrating plant litter quality, soil organic matter stabilization, and the carbon saturation concept. Glob Change Biol. 2015:21(9):3200-9.

32. Yé $L$, et al. Contrasted effects of annual and perennial grasses on soil chemical and biological characteristics of a grazed Sudanian savanna. Appl Soil Ecol. 2017;113:155-65.

33. Yu P, et al. Soil organic carbon fractions are affected by different land uses in an agro-pastoral transitional zone in Northeastern China. Ecol Ind. 2017:73:331-7.

34. County Government of West Pokot. First County Integrated Development Plan 2013-2017; 2013. http://www.westpokot.go.ke/. Accessed 2 Dec 2017

35. Hiederer R, Köchy M. Global soil organic carbon estimates and the harmonized world soil database. EUR. 2011;79:25225.

36. Oduor CO. Managing soil organic carbon and greenhouse gas emissions through the establishment of pasture enclosures in West Pokot County, Kenya. In: Department of Land Resource Management and Agricultural Technology (LARMAT). Thesis. Nairobi: University of Nairobi; 2018. p. $1-100$ 
37. Reynolds S. The gravimetric method of soil moisture determination Part IA study of equipment, and methodological problems. J Hydrol. 1970;11(3):258-73.

38. Blake GR. Physical and mineralogical properties, including statistics of measurement and sampling. In: Black CA, editor. Methods of soil analysis, Part 1, ASA-SSSA, vol. 9. Agronomy Monograph; 1965. pp. 374-90.

39. Bouyoucos GJ. Hydrometer method improved for making particle size analyses of soils. Agron J. 1962;54(5):464-5.

40. Nelson DW, Sommers LE. Total carbon, organic carbon and organic matter. In: Page AL, Miller RH, Keeney DR, editors. Methods of soil analysis. Part 2 Chemical and microbiological properties; 1982. pp. 539-79.

41. Kjeldahl J. A new method for the determination of nitrogen in organic matter. Z Anal Chem. 1883;22(1):366-82.

42. Chapman HD. Cation exchange capacity. In: Black CA, editor. Methods of soil analysis. Madison: American Society of Agronomy; 1965. pp. 891-901.

43. Cambardella C, Elliott E. Particulate soil organic-matter changes across a grassland cultivation sequence. Soil Sci Soc Am J. 1992;56(3):777-83.

44. Vance ED, Brookes PC, Jenkinson DS. An extraction method for measuring soil microbial biomass C. Soil Biol Biochem. 1987;19(6):703-7.

45. Nunan N, Morgan M, Herlihy M. Ultraviolet absorbance $(280 \mathrm{~nm})$ of compounds released from soil during chloroform fumigation as an estimate of the microbial biomass. Soil Biol Biochem. 1998;30(12):1599-603.

46. Beck T, et al. An inter-laboratory comparison of ten different ways of measuring soil microbial biomass C. Soil Biol Biochem. 1997;29(7):1023-32.

47. Brookes $P C$, et al. Chloroform fumigation and the release of soil nitrogen: a rapid direct extraction method to measure microbial biomass nitrogen in soil. Soil Biol Biochem. 1985;17:837-42.

48. VSN International. GenStat for windows. 15th ed. Hemel Hempstead: VSN International; 2012.

49. SPSS, I. IBM SPSS statistics for Windows, version 20.0. New York: IBM Corp; 2011.

50. McKenzie NJ, et al. Australian soils and landscapes: an illustrated compendium. Melbourne, Australia: CSIRO Publishing; 2004.

51. USDA. Rangeland soil quality — compaction. Soil Quality Institute, Grazing Lands Technology Institute, and National Soil Survey Center, Natural Resources Conservation Service. 2001. https://www.nrcs.usda.gov/Inter net/FSE DOCUMENTS/nrcs142p2 051912.pdf.

52. Kinyua $D$, et al. Short-term and long-term effects of soil ripping, seeding, and fertilization on the restoration of a tropical rangeland. Restor Ecol. 2010;18(s1):226-33.

53. Yong-Zhong $S$, et al. Influences of continuous grazing and livestock exclusion on soil properties in a degraded sandy grassland, Inner Mongolia, northern China. CATENA. 2005;59(3):267-78.

54. Castellano $\mathrm{M}$, Valone $\mathrm{T}$. Livestock, soil compaction and water infiltration rate: evaluating a potential desertification recovery mechanism. J Arid Environ. 2007:71(1):97-108.

55. Hudson BD. Soil organic matter and available water capacity. J Soil Water Conserv. 1994:49(2):189-94.

56. Benbi DK, et al. Total and labile pools of soil organic carbon in cultivated and undisturbed soils in Northern India. Geoderma. 2015;237-238:149-58

57. Jeddi $K$, Chaieb M. Changes in soil properties and vegetation following livestock grazing exclusion in degraded arid environments of South Tunisia. FloraMorphol Distrib Funct Ecol Plants. 2010;205(3):184-9.
58. Mekuria W, Aynekulu E. Exclosure land management for restoration of the soils in degraded communal grazing lands in northern Ethiopia. Land Degrad Dev. 2011;24:528-38.

59. Svanlund S. Carbon sequestration in the pastoral area of Chepareria, western Kenya - a comparison between open-grazing, fenced pastures and maize cultivations. Department of Forest Ecology and Management, Swedish University of Agricultural Sciences, Faculty of Forest Sciences; 2014. pp. 1-38. http://www.triplel.se/publications/msc-thesis/2-carbo n-sequestration-in-the-pastoral-area-of-chepareria-western-kenya-mscthesis-sara-svanlund-slu/file.html.

60. Ituika AG. Impact of enclosure management and age on topsoil organic carbon stocks in Chepareria, West Pokot County, Kenya. Ghent: Ghent University; 2016.

61. Roldan A, et al. Changes in soil enzyme activity, fertility, aggregation and C sequestration mediated by conservation tillage practices and water regime in a maize field. Appl Soil Ecol. 2005;30:11-20.

62. Conant RT, Six J, Paustian K. Land use effects on soil carbon fractions in the southeastern United States. I. Management-intensive versus extensive grazing. Biol Fertil Soils. 2003;38(6):386-92.

63. Plaza-Bonilla D, Álvaro-Fuentes J, Cantero-Martínez C. Identifying soil organic carbon fractions sensitive to agricultural management practices. Soil Tillage Res. 2014;139:19-22.

64. Burke IC, Lauenroth WK, Coffin DP. Soil organic matter recovery in semiarid grasslands: implications for the conservation reserve program. Ecol Appl. 1995;5(3):793-801.

65. Goebel M-O, Woche SK, Bachmann J. Do soil aggregates really protect encapsulated organic matter against microbial decomposition? Biologia. 2009;64(3):443-8

66. Yost $J$, et al. Impact of restoration and management on aggregation and organic carbon accumulation in urban grasslands. Soil Sci Soc Am J. 2016:80(4):992-1002

67. Six J, et al. Aggregation and soil organic matter accumulation in cultivated and native grassland soils. Soil Sci Soc Am J. 1998;62(5):1367-77.

68. Gale W, Cambardella C, Bailey T. Root-derived carbon and the formation and stabilization of aggregates. Soil Sci Soc Am J. 2000;64(1):201-7.

69. Chan K. Consequences of changes in particulate organic carbon in vertisols under pasture and cropping. Soil Sci Soc Am J. 1997;61(5):1376-82.

70. Gill $\mathrm{R}$, et al. Relationship between root biomass and soil organic matter pools in the shortgrass steppe of eastern Colorado. Ecosystems. 1999;2(3):226.

71. Kaye J, Barrett J, Burke I. Stable nitrogen and carbon pools in grassland soils of variable texture and carbon content. Ecosystems. 2002;5(5):461-71.

72. Liu N, et al. Impact of grazing on soil carbon and microbial biomass in typical steppe and desert steppe of Inner Mongolia. PLOS ONE. 2012; 7:e36434

73. Weber B, et al. Natural recovery of biological soil crusts after disturbance, in biological soil crusts: an organizing principle in Drylands. Berlin: Springer; 2016. p. 479-98.

74. Buyanovsky G, Aslam M, Wagner G. Carbon turnover in soil physical fractions. Soil Sci Soc Am J. 1994;58(4):1167-73.

75. Schlesinger WH, Andrews JA. Soil respiration and the global carbon cycle. Biogeochemistry. 2000;48(1):7-20.

Ready to submit your research? Choose BMC and benefit from:

- fast, convenient online submission

- thorough peer review by experienced researchers in your field

- rapid publication on acceptance

- support for research data, including large and complex data types

- gold Open Access which fosters wider collaboration and increased citations

- maximum visibility for your research: over 100M website views per year

At $\mathrm{BMC}$, research is always in progress.

Learn more biomedcentral.com/submissions 